\title{
COVID-19 and the Australian labour market: how did older Australians fare during 2020?
}

Jane Fry The University of Melbourne

Jeromey B. Temple* The University of Melbourne

Peter McDonald The University of Melbourne

Alysia Blackham The University of Melbourne

*Corresponding author. Email: Jeromey.Temple@unimelb.edu.au. Address: Melbourne School of Population and Global Health, The University of Melbourne, Melbourne, VIC, 3010, Australia

Paper received 29 June 2021; accepted 25 October 2021; published 29 November 2021

\begin{abstract}
Background

In analysing the effects of the COVID-19 pandemic on the labour market, attention has focussed on younger people, leaving a research gap when it comes to outcomes for older Australians aged 50 years or over, in terms of employment, unemployment, underemployment and hours worked.
\end{abstract}

\section{Aims}

To describe levels of labour force participation, unemployment, underemployment, and hours worked by older workers and job seekers during 2020.

\section{Data and methods}

Using Australian Bureau of Statistics data, we perform descriptive analyses of variations in labour market outcomes by geographic areas, public and private sector employment, industry of employment and demographic characteristics.

\section{Results}

Older employment fell in April but recovered by December. As the full-time share initially increased, average hours worked decreased due to reductions in hours offered to workers, increasing the underemployment rate. There was little recovery of employment in metropolitan Melbourne due to prolonged lockdown conditions. Of the largest industries, retail trade and manufacturing were worst affected.

\section{Conclusions}

By December 2020, employment levels for older workers in some sectors had recovered from the initial downturn caused by the pandemic. However, for older workers in some industries, there is a major concern about their potential for future employment.

\section{Key words}

Older workers; COVID-19; labour market; retirement. 


\section{Introduction}

As of March 2021, approximately one third of all COVID-19 cases in Australia were among people aged 50 years and over, with this same group accounting for $99 \%$ of COVID-19 deaths, the majority of which were aged over 70 years (Department of Health 2021). In terms of individual health and mortality, COVID-19 has heavily impacted older Australians (typically aged 50 years or over), while younger Australians (defined here as those aged 15-24 years) have faced particularly deleterious effects on their mental health and general wellbeing (Varma et al. 2021). Although younger Australians have faced considerable increases in unemployment and underemployment (Churchill 2020), little attention has been given to how older workers and job seekers have fared in 2020 during the COVID-19 pandemic.

Ordinarily, we would expect older workers to fare worse, as they do in other recessions, with reduced employment opportunities (Chomik 2020), increased age discrimination in recruitment, and steep wage losses (Bui et al. 2020), especially given they are more vulnerable to the effects of COVID19. That said, this may not be the case, because younger workers are more casualised and therefore more easily laid off (Borland \& Charlton 2020). There remains uncertainty as to the long-term effects on particular groups of workers, particularly on the basis of gender, age, and in particular sectors (Birch \& Preston 2020) as shutdowns have led to job loss, unemployment and inactivity (Chomik 2020).

In this paper we address this research gap through a detailed examination of labour force participation, unemployment, underemployment, and hours worked by older workers (aged 50 years or over) and job seekers during the COVID-19 pandemic in 2020. At the urging of unions and some business groups, the Australian Government introduced the JobKeeper wage subsidy scheme to help keep more people employed in private businesses and not-for-profit organisations. A number of OECD countries have introduced similar job retention (wage subsidy) schemes, such as New Zealand, Canada, Estonia, Poland and the Netherlands (OECD 2020). Under JobKeeper, eligible employers were required to pay a minimum of $\$ 1,500$ per fortnight to the employee (Forsyth 2020). JobKeeper objectives were to support business and job survival, preserve employment relationships, and provide needed income support (Neil et al. 2021). It continued throughout the period of observation used in this paper, March to December 2020. The effects of the JobKeeper payments on employment are an important backdrop to the paper given that JobKeeper essentially disguises unemployment (Coates et al. 2020).

This research complements the detailed evidence base on older labour force participation, including, but not limited to, the determinants, barriers and enablers of older employment, the role of workplaces and the efficiency of government policy in enabling participation and futures of labour supply (OECD 1998; Adair \& Temple 2012; Yeatts et al. 2000). Apart from providing a complementary view to previous studies, our analysis underscores the impacts of COVID-19 on older workers. 


\section{Data and methods}

In this paper, we use population-weighted Australian Bureau of Statistics (ABS) data tables based on the Labour Force Survey. This survey of approximately 50,000 individuals in 26,000 dwellings is conducted monthly, with households interviewed for eight consecutive months. The nationally representative sample rotates with one eighth of the households replaced each month. In scope individuals are civilians aged 15 years and over. In addition to socio-demographic information, questions relate to labour market activities in a 'reference week' just prior to the survey. More information on the sample and survey methodology are available elsewhere (ABS 2021c), as are the underlying data tables (ABS 2021b).

Within the ABS Labour Force Framework there are seven key concepts for analysing labour market performance:

1. Population is identified as the number of usually resident civilians in the relevant age/sex group.

2. Employment is defined as engaged in full-time or part-time work.

3. Hours worked (in our context) is hours actually worked in all jobs.

4. Underemployment is defined as either:

a) employed full-time but worked less than 35 hours in the reference week due to economic reasons and available to work more hours, or

b) employed part-time and would prefer more hours and available to work more hours.

5. Unemployment is defined as not employed but waiting to start a new job or actively looking for work.

6. The labour force comprises individuals who are employed or unemployed.

7. Not in the labour force (NILF) comprises individuals who are neither employed nor unemployed. Further details are available elsewhere (ABS 2018).

These concepts are then used to calculate six summary measures:

1. Employment to population ratios divide the number employed (full-time or part-time) by the population.

2. Labour force participation rates divide the labour force by population.

3. Unemployment rates divide the number unemployed by the labour force.

4. Underemployment rates divide the number underemployed by the labour force.

5. Hours per worker divides total hours of actual work by the number employed.

6. Full-time share divides the number of full-time employed by the total number employed.

We refine our aggregate analysis to consider geographic areas, public and private sector employment, industry of employment and demographic characteristics.

Summary measures are provided for March 2020 (or the February quarter), the initial period, which compares March and April (or the May quarter) to gauge the initial effect; and the longer period, which compares March with December (or the November quarter) to gauge the 2020 effect. These effects are percentage changes for selected concepts (such as the number employed) or percentage point changes for summary measures (except hours per worker, where we use percentages).

Ethics approval for this project was granted by The University of Melbourne Human Ethics Committee LNR 2A - Ethics ID 2021-21421-15592-2. 


\section{Results}

\subsection{Aggregate effects}

Initially, young people fared the worst: their employment rate fell by more than six points (Table 1 ). Most who lost their jobs withdrew from the labour force, cushioning the effect on the unemployment rate. Job losses occurred despite the JobKeeper program, for which there were 900,000 applicants per month up to September, then 500,000 applicants per month through the remainder of the year. A recovery by December left the employment rate at March levels, although an increase in participation raised the unemployment rate as more individuals searched for work. Initially, hours worked dropped due to the combined effects of a loss of part-time jobs and reduced hours for remaining workers. This served to increase underemployment among the youngest workers. In the longer period, hours worked more than recovered, and desired and actual hours worked were in balance.

Table 1: Effect of COVID-19 on employment and participation by age group, Australia, 2019 and 2020

\begin{tabular}{|c|c|c|c|c|c|}
\hline & March 2020 & $\begin{array}{l}\text { March-April } \\
2020 \text { change }\end{array}$ & $\begin{array}{c}\text { March-April } \\
2019 \\
\text { change }\end{array}$ & $\begin{array}{c}\text { March- } \\
\text { December } \\
2020 \text { change }\end{array}$ & $\begin{array}{c}\text { March- } \\
\text { December } \\
2019 \text { change }\end{array}$ \\
\hline \multicolumn{6}{|l|}{ Age $15-24$ years } \\
\hline Participation rate & $68.9 \%$ & -6.4 points & -0.3 points & +1.8 points & +2 points \\
\hline Employment rate & $60.2 \%$ & -6.5 points & +0.3 points & +0.6 points & +2.6 points \\
\hline Unemployment rate & $12.7 \%$ & +1.5 points & -0.9 points & +1.3 points & -1.2 points \\
\hline Full-time share & $43.7 \%$ & +1.5 points & -1.3 points & -0.2 points & +0.2 points \\
\hline Hours per worker & 24.9 hours & $-16.4 \%$ & $-2.0 \%$ & $+4.6 \%$ & $+1.7 \%$ \\
\hline Underemployment rate & $18.1 \%$ & +4.5 points & +0.8 points & +0.4 points & +3.5 points \\
\hline \multicolumn{6}{|l|}{ Age $25-49$ years } \\
\hline Participation rate & $85.7 \%$ & -2 points & +0.3 points & +0.4 points & +0.6 points \\
\hline Employment rate & $82.1 \%$ & -2.8 points & +0.3 points & -0.2 points & +1 point \\
\hline Unemployment rate & $4.3 \%$ & +1.1 points & 0 points & +0.6 points & -0.5 points \\
\hline Full-time share & $75.5 \%$ & +0.6 points & -0.2 points & +0.1 points & +0.2 points \\
\hline Hours per worker & 34.3 hours & $-11.4 \%$ & $-1.8 \%$ & $+3.4 \%$ & $+2.2 \%$ \\
\hline Underemployment rate & $6.7 \%$ & +5.5 points & +0.3 points & +0.7 points & -0.1 points \\
\hline \multicolumn{6}{|l|}{ Age $50+$ years } \\
\hline Participation rate & $45.0 \%$ & -1.5 points & 0 points & +0.4 points & 0 points \\
\hline Employment rate & $43.1 \%$ & -1.6 points & 0 points & +0.1 points & +0.1 points \\
\hline Unemployment rate & $4.1 \%$ & +0.4 points & +0.1 points & +0.6 points & -0.2 points \\
\hline Full-time share & $66.2 \%$ & +1.3 points & -0.3 points & +0.8 points & -0.2 points \\
\hline Hours per worker & 32.5 hours & $-9.7 \%$ & $-0.3 \%$ & $+2.7 \%$ & $+2.2 \%$ \\
\hline $\begin{array}{l}\text { Underemployment rate } \\
\text { (aged } 55+\text { years) }\end{array}$ & $6.9 \%$ & +4.3 points & +0.2 points & -0.4 points & +0.5 points \\
\hline
\end{tabular}

Source: ABS Labour Force Survey. Note: The age group used for underemployment differ from those of the other measures because of the availability of data. Points refers to percentage points.

Among individuals aged $25-49$ years there was also a marked reduction in participation and employment in the initial period. Hours per worker fell substantially $(11 \%)$ and underemployment rose. However, by December labour market conditions were almost the same as in March, although 
hours worked were higher. At first, the fall in the employment rate among older workers was matched almost exactly by a fall in participation. Initially, therefore, workers losing their jobs defined themselves as being out of the labour force. This meant the rise in the unemployment rate was much smaller than may have been expected. In the longer period, the fall in employment for older workers was fully compensated, but the participation rate rose more than the employment rate. Thus, in the longer period, the unemployment effect was worse than it had been in the initial period.

Participation was higher in December than in March but does not appear to be seasonal based on a comparison with the March-December 2019 change.

A reduction in part-time jobs (many held on a casual basis) led to a small increase in the full-time/ part-time job share. However, average hours per worker declined as workers initially faced reduced hours. In particular, fewer casual workers in food, hospitality and other service industries were required due to sector-specific closures and limits on social gatherings. Some employers reduced the hours offered to employees rather than laying them off. Indeed, for employees aged 55 years and over, a comparison between August 2019 and 2020 shows a large increase in employees citing not enough work as a reason for working fewer hours than usual: a three-fold increase for employees with paid leave entitlements and a 50\% increase for employees without paid leave (casual) (ABS 2021a).

\subsection{Distributional results: geographical areas}

The initial effect of COVID-19 on the participation of older workers was similar across all the geographies shown in Table 2, but was a little higher in Western Australia where the prevalence of COVID-19 was lower. This suggests that people who lost jobs initially reacted to the pandemic announcement by leaving the labour force. The same effects are evident for employment at the state level and for regional Australia, with the fall in employment roughly matching the fall in participation - implying minimal impact overall on unemployment. However, regional Victoria differs from other areas in that, while participation also fell, employment fell much less than elsewhere. The implied reduction in unemployment is consistent with the reduction in the participation rate.

Table 2: Effect of COVID-19 on the employment and participation of workers aged 50 and over, selected states, metropolitan Melbourne and regional Victoria, 2020

\begin{tabular}{|c|c|c|c|c|c|c|}
\hline & \multicolumn{3}{|c|}{ Participation rate } & \multicolumn{3}{|c|}{ Employment rate } \\
\hline & $\begin{array}{c}\text { March } \\
2020\end{array}$ & $\begin{array}{c}\text { March-April } \\
\text { change }\end{array}$ & $\begin{array}{l}\text { March- } \\
\text { December } \\
\text { change }\end{array}$ & $\begin{array}{c}\text { March } \\
2020\end{array}$ & $\begin{array}{c}\text { March-April } \\
\text { change }\end{array}$ & $\begin{array}{l}\text { March- } \\
\text { December } \\
\text { change }\end{array}$ \\
\hline New South Wales & $43.4 \%$ & -1.3 points & +1.1 points & $41.6 \%$ & -1.5 points & +0.5 points \\
\hline Western Australia & $49.0 \%$ & -1.6 points & +0.2 points & $46.4 \%$ & -1.5 points & +0.1 points \\
\hline Victoria & $45.7 \%$ & -1.3 points & 0 points & $44.0 \%$ & -1.1 points & -0.3 points \\
\hline Metropolitan & $46.2 \%$ & -1.2 points & -0.5 points & $44.6 \%$ & -1.3 points & -1.0 points \\
\hline Melbourne & & & & & & \\
\hline Regional Victoria & $44.3 \%$ & -1.4 points & +1.1 points & $42.7 \%$ & -0.5 points & +1.4 points \\
\hline Regional Australia & $42.8 \%$ & -1.3 points & +0.4 points & $41.1 \%$ & -1.2 points & +0.6 points \\
\hline
\end{tabular}

Source: ABS Labour Force Survey. Note: Points refers to percentage points. 
In the longer period, as might have been expected given the duration of the second lockdown in metropolitan Melbourne, there was little recovery of employment in metropolitan Melbourne while there was strong recovery everywhere else, especially in regional Victoria. While population levels remained stable between metropolitan Melbourne and regional Victoria, metropolitan Melbourne's share of employment declined, suggesting jobs may have shifted to regional Victoria.

\subsection{Employment by age group and sector}

Considering individuals aged 45 years or over, initially the numbers employed fell for all of the older age groups in both the public and the private sectors, but the largest percentage falls tended to be in the older ages 60-64 and 65+ years, especially in the public sector (Table 3). In the longer period, in the public sector, recovery was very strong for all age groups, especially among 50-59 year olds. In the longer period, in the private sector, there was recovery for the two oldest age groups. This may mean that, unlike in previous recessions, 2020 may not lead to a growth in early retirement (Rutledge \& Coe 2012).

Table 3: Numbers employed and percentage changes in numbers employed by age group and sector, Australia, 2020

\begin{tabular}{lcccccc}
\hline & \multicolumn{3}{c}{ Public sector } & \multicolumn{3}{c}{ Private sector } \\
Age group & $\begin{array}{c}\text { No. employed } \\
\text { March 2020 }\end{array}$ & \multicolumn{2}{c}{ \% change } & No. employed & \% change \\
& $($ '000) & April & Mecember & ('000) & April & December \\
\hline $45-49$ & 255.9 & -2.9 & +2.2 & 1137.0 & -3.9 & -2.8 \\
$50-54$ & 220.5 & -5.9 & +5.8 & 1029.9 & -3.1 & -0.5 \\
$55-59$ & 204.4 & -3.1 & +8.4 & 923.9 & -3.8 & -2.8 \\
$60-64$ & 150.6 & -8.1 & +1.7 & 645.2 & -1.7 & +2.6 \\
$65+$ & 80.6 & -14.3 & +1.4 & 517.8 & -9.3 & +3.1 \\
\hline
\end{tabular}

Source: ABS Labour Force Survey.

\subsection{Employment by industry}

Between February and May, employment of older workers fell by between 4 and 9 per cent for the six largest industries of employment (Table 4). However, in the longer period, the outcomes for these six industries varied considerably, rising by 10.4 per cent for education and training but falling by 11.2 per cent for manufacturing. Retail also showed a heavy fall in the longer period. For the other three largest industries, employment returned to its February level by November.

For the remaining industries, there were some for which the February to May effect was positive (construction (perhaps boosted by the 'HomeBuilder' program); agriculture, forestry and fishing; wholesale trade; financial and insurance services; rental, hiring and real estate services; electricity, gas, water and waste services). COVID-19 gave rise to issues of distribution which may account for the strong positive result for wholesale trade. There were strong negative initial outcomes for arts and recreation services and for accommodation and food services, due in part to spatial distancing measures (Coates et al. 2020).

Between February and November, sectors outside the top six that had positive initial outcomes had - not unexpectedly - positive longer-term outcomes as well. That said, there were some 
strong reversals for a few industries that had negative initial outcomes. For example, employment in accommodation and food services swung from an initial fall to a longer period gain.

Administrative and support services, accommodation and food services and mining also showed a large turnaround from negative to positive from the initial period to the longer period

Table 4: Numbers employed and percentage change in numbers employed by industry, workers aged 50+ years, Australia, 2020

\begin{tabular}{lccc}
\hline Industry (in rank order of employment) & $\begin{array}{c}\text { Number employed } \\
\text { February 2020 } \\
\text { ('000s) }\end{array}$ & $\begin{array}{r}\text { Percentage change in number } \\
\text { employed }\end{array}$ \\
& & $\begin{array}{c}\text { February to } \\
\text { May 2020 }\end{array}$ & $\begin{array}{c}\text { February to } \\
\text { November 2020 }\end{array}$ \\
\hline Health care and social assistance & 597.8 & -4.0 & -2.2 \\
Education and training & 345.9 & -3.6 & +10.4 \\
Professional, scientific and technical services & 305.1 & -5.3 & -0.4 \\
Retail trade & 300.3 & -8.9 & -6.7 \\
Manufacturing & 295.4 & -6.9 & -11.2 \\
Public administration and safety & 292.1 & -4.6 & +0.1 \\
Construction & 288.3 & +1.1 & +5.5 \\
Transport, postal and warehousing & 260.6 & -15.9 & -6.3 \\
Agriculture, forestry and fishing & 174.9 & +6.3 & 0 \\
Other services & 139.5 & -16.5 & -3.2 \\
Wholesale trade & 126.8 & +10.9 & +7.8 \\
Administrative and support services & 125.3 & -3.5 & +12.6 \\
Accommodation and food services & 123.5 & -11.4 & +12.7 \\
Financial and insurance services & 115.0 & +12.5 & +7.5 \\
Rental, hiring and real estate services & 69.7 & +2.1 & +8.2 \\
Arts and recreation services & 62.6 & -20.2 & -3.6 \\
Mining & 60.6 & -9.0 & +12.7 \\
Information, media and telecommunications & 53.4 & -23.5 & -6.7 \\
Electricity, gas, water and waste services & 36.1 & +36.0 & +41.2 \\
\hline
\end{tabular}

Source: ABS Labour Force Survey. Note: The periods used in this table differ from those of other tables because of the availability of data.

\subsection{Employment by demographic characteristics}

Initially, individuals aged 50-64 years from North-East Asia were worst hit by declining employment rates, although they recovered well (Table 5). Individuals aged 50-64 years from the Americas did not fare well, with an initial reduction of 3 percentage points followed by further decline in the longer period. Among those aged 65 years or over, highest employment rates were for individuals from Oceania/Antarctica and Sub-Saharan Africa. Alongside North Africa/Middle East and the Americas, they have the largest initial reductions in employment. However, rates for Oceania and the Americas recovered well, increasing by 2 and 6 percentage points respectively over the longer period. 
Table 5: Percentage employed and changes in percentage employed by age group by country of birth, sex, partner status, relationship status and education, Australia 2020

\begin{tabular}{|c|c|c|c|c|c|c|}
\hline \multirow[t]{2}{*}{ Characteristic } & \multicolumn{3}{|c|}{$50-64$} & \multicolumn{3}{|c|}{$65+$} \\
\hline & $\begin{array}{l}\text { Mar } 2020 \\
\% \text { empl'd }\end{array}$ & $\begin{array}{l}\text { Mar-Apr } \\
\text { change }\end{array}$ & $\begin{array}{l}\text { Mar-Dec } \\
\text { change }\end{array}$ & $\begin{array}{l}\text { Mar } 2020 \\
\% \text { empl'd }\end{array}$ & $\begin{array}{l}\text { Mar-Apr } \\
\text { change }\end{array}$ & $\begin{array}{l}\text { Mar-Dec } \\
\text { change }\end{array}$ \\
\hline \multicolumn{7}{|l|}{ Country of birth } \\
\hline Australia & 71.3 & $-1.5 \mathrm{pts}$ & $-0.1 \mathrm{pts}$ & 15.9 & $-1.1 \mathrm{pts}$ & $0.3 \mathrm{pts}$ \\
\hline Oceania and Antarctica & 72.6 & $-2.9 \mathrm{pts}$ & $3.1 \mathrm{pts}$ & 21.9 & -3 pts & $2.1 \mathrm{pts}$ \\
\hline North-West Europe & 74.3 & $-2.9 \mathrm{pts}$ & -0.1 pts & 13.3 & $-1.6 \mathrm{pts}$ & $-0.1 \mathrm{pts}$ \\
\hline Southern and Eastern Europe & 64.7 & $-2.2 \mathrm{pts}$ & $-2.8 \mathrm{pts}$ & 8.2 & $-1.2 \mathrm{pts}$ & $0.2 \mathrm{pts}$ \\
\hline North Africa and the Middle East & 41.2 & $-1.4 \mathrm{pts}$ & $2.4 \mathrm{pts}$ & 9.8 & $-3.5 \mathrm{pts}$ & $-0.2 \mathrm{pts}$ \\
\hline South-East Asia & 64.4 & $-2.7 \mathrm{pts}$ & -0.6 pts & 16.4 & $0.9 \mathrm{pts}$ & $-0.1 \mathrm{pts}$ \\
\hline North-East Asia & 54.0 & $-6.8 \mathrm{pts}$ & $3.3 \mathrm{pts}$ & 8.3 & -1.6 pts & $3.9 \mathrm{pts}$ \\
\hline Southern and Central Asia & 72.9 & $-1.1 \mathrm{pts}$ & -2.7 pts & 17.8 & $1.1 \mathrm{pts}$ & 2 pts \\
\hline Americas & 71.1 & -3 pts & -4.1 pts & 15.8 & $-3.1 \mathrm{pts}$ & 6 pts \\
\hline Sub-Saharan Africa & 79.1 & $-1.7 \mathrm{pts}$ & -5.4 pts & 19.3 & $-2.6 \mathrm{pts}$ & $0.3 \mathrm{pts}$ \\
\hline \multicolumn{7}{|l|}{ Sex } \\
\hline Males & 74.9 & $-1.7 \mathrm{pts}$ & $-0.4 \mathrm{pts}$ & 17.7 & $-1.3 \mathrm{pts}$ & $1.3 \mathrm{pts}$ \\
\hline Females & 64.8 & $-2.2 \mathrm{pts}$ & $0.3 \mathrm{pts}$ & 10.9 & $-0.9 \mathrm{pts}$ & $0.1 \mathrm{pts}$ \\
\hline \multicolumn{7}{|l|}{ Partner status } \\
\hline Partnered & 73.3 & $-2.3 \mathrm{pts}$ & $0.1 \mathrm{pts}$ & 16.5 & $-1.3 \mathrm{pts}$ & +1.9 pts \\
\hline Not partnered & 60.8 & $-1.2 \mathrm{pts}$ & -0.5 pts & 10.4 & $-0.9 \mathrm{pts}$ & $-1.5 \mathrm{pts}$ \\
\hline \multicolumn{7}{|l|}{ Relationship status } \\
\hline Has spouse only & 69.1 & $-2.5 \mathrm{pts}$ & $-0.4 \mathrm{pts}$ & 16.1 & $-1.6 \mathrm{pts}$ & $1.4 \mathrm{pts}$ \\
\hline Has dependent children & 76.7 & $-2.5 \mathrm{pts}$ & $0.3 \mathrm{pts}$ & 18.0 & $-0.5 \mathrm{pts}$ & $2.2 \mathrm{pts}$ \\
\hline Lone person & 61.2 & $-0.5 \mathrm{pts}$ & $1 \mathrm{pts}$ & 12.1 & $-0.9 \mathrm{pts}$ & $-2.5 \mathrm{pts}$ \\
\hline Other & 51.3 & $-0.6 \mathrm{pts}$ & -2.7 pts & 6.0 & $-0.3 \mathrm{pts}$ & $0.6 \mathrm{pts}$ \\
\hline \multicolumn{7}{|l|}{ Education } \\
\hline Bachelor and above & 78.3 & $-2.5 \mathrm{pts}$ & $0.5 \mathrm{pts}$ & 24.6 & $-3.1 \mathrm{pts}$ & $+0.8 \mathrm{pts}$ \\
\hline Diplomas, Advanced Diplomas & 76.8 & $-3.3 \mathrm{pts}$ & -2.4 pts & 19.2 & $+1.1 \mathrm{pts}$ & $-0.5 \mathrm{pts}$ \\
\hline Certificate III/IV & 75.9 & $-2.4 \mathrm{pts}$ & -0.1 pts & 17.7 & $-2.5 \mathrm{pts}$ & $-0.7 \mathrm{pts}$ \\
\hline Year 12 & 68.2 & $-4.3 p t s$ & $-1.3 \mathrm{pts}$ & 14.2 & $-2.1 \mathrm{pts}$ & $+1.3 \mathrm{pts}$ \\
\hline Below Year 12 & 56.2 & $-2.1 \mathrm{pts}$ & $-0.3 \mathrm{pts}$ & 10.2 & $-1.2 \mathrm{pts}$ & $-1.1 \mathrm{pts}$ \\
\hline
\end{tabular}

Source: ABS Labour Force Survey. Note: Other relationships include non-dependent child, other related individual, nonfamily members and visitors. Pts refers to percentage points.

The initial reduction in the employment rate fell disproportionately for females and partnered individuals aged 50-64 years (Birch \& Preston 2021), although these older individuals were not disadvantaged in the longer period (however, Wood et al. (2021) find women's overall employment remains below pre-COVID-19 levels). Hidden behind the overall recovery in employment rates in the longer term was a gain for males and partnered individuals aged 65 years or over. Hardest hit by the initial reduction in employment were individuals aged 50-64 years with a spouse and/or dependent children. However, their prospects improved over the longer period. By December, the largest losses of employment were among lone persons aged 65 years or over (-2.5 points), but older individuals with dependent children increased their employment by 2.2 points. 
Among those with identified education levels and aged 50-64 years, all experienced an initial decline in employment, particularly individuals with Year 12 (which concords with ISCED 3, upper secondary) or Diplomas and Advanced Diplomas. Individuals with Diplomas and Advanced Diplomas were particularly disadvantaged as their employment rates did not recover by December. This is an occupational effect associated with the decline in roles in the health care and social assistance sector. Among those aged 65 years or over, the largest initial reduction in employment is for holders of Bachelor's Degrees and above, associated with sectoral contractions in health care and social assistance, education and training, and professional, scientific and technical services. However, driven by growth in education and training, this group recovers over the longer period.

\section{Discussion}

The impacts of COVID-19 on Australian employment in 2020 exacerbated and exposed inequalities in the labour market (Birch \& Preston 2021). Initially, employment rates fell between March and April 2020 for almost all groups, regions and industries included in the study. Young people were hardest hit due to their overrepresentation in casual employment and in service industries hardest hit by lockdown restrictions. However, older workers also suffered. Overall, there were initial period negative effects as older workers exited the labour force, but the economic recovery and policy responses such as JobKeeper (with uptake of $3.8 \%$ in December) and working from home appear to have ameliorated the longer period effects. The pandemic was initially broadly perceived to be an event that would have a strong negative impact on business and, hence, on employment. Later, when businesses and organisations obtained access to JobKeeper, and the pandemic's impact in some geographic areas was not large, employment recovered steadily. Thus, the employment impacts of COVID in Australia were buffered in regions where case numbers were low. The introduction of government policies like JobKeeper (which favoured those in non-casualised employment) reduced the impact for some groups, such as older workers. At a national level, then, the long-term impact of 2020 on the employment outcomes for older workers is likely to be different to other recessions because the economic costs are likely to persist (Coates et al. 2020).

In terms of geography, we concentrated primarily upon Victoria, but comparison was made with New South Wales, a similar state in economic terms (Gross State Product per capita); and with Western Australia, where COVID-19 was least prevalent among the states. Initially, COVID-19 was slightly more prevalent in New South Wales than in Victoria. However, Victoria had a very large second wave not experienced by New South Wales, and that experience was confined largely to metropolitan Melbourne. As the prevalence of COVID-19 was heavily concentrated in cities, we compare with regional Australia and regional Victoria. These results reflect a natural experiment: Victoria was subject to the same employment support policies as the rest of Australia because those policies were mainly Federal (the exception being paid pandemic leave for COVID-19 testing and associated selfisolation). The different effects between Victoria, New South Wales and Western Australia were therefore due (almost) purely to the different experience of COVID-19 (besides any changes that would have taken place in the absence of COVID-19, which can be expected to be very small in the short term). The same argument can be made about metropolitan Melbourne and regional Victoria. The reason Victoria (particularly regional Victoria) had a smaller contraction in employment is that it is less intensive in mining, and, to a lesser extent, accommodation and food services and other services sectors, which all suffered large reductions in employment. 
By December 2020, there were few instances where employment loss remained considerable. The main exceptions where employment effects were still negative at the end of 2020 were people living in metropolitan Melbourne, private sector workers aged 50-59 years, people living alone aged 65 years and over, and those with the lowest education qualification. In the private sector, for those aged 45-60 years, the initial negative impact on employment numbers was largely sustained in the longer period. This may indicate that private sector employers took the opportunity to retrench some older, lower skilled workers. Data not shown here reveal that outcomes were worse for occupations at the lower end of the skills spectrum, although this was not always the case. For example, strongly negative outcomes in the longer period were evident for food preparation assistants, farm forestry and garden workers, sales support workers, and clerical and office support workers. On the other hand, there was a private sector recovery for those aged 60 years or over and this could be because these people tend to be self-employed or employed as managers/professionals and had more control over their own employment. In terms of occupations, for storepersons, a low skilled job, there were strong positive results in the longer period, probably because COVID-19 stimulated jobs in this occupation.

Overall, while the national picture for older workers appeared positive by the end of 2020, lowerskilled workers in some sectors experienced significant deleterious effects. Long-term job loss for older workers was concentrated in the following industries: manufacturing; retail; health care and social administration; transport, postal, warehouse; arts and recreation; and information, media and telecommunications. The immediate effects of COVID-19 on these industries were obvious as entertainment venues, cafes and restaurants were closed, and hotels were affected by travel restrictions. Lockdowns probably also prevented information, media and telecommunications industries operating as normal. The large initial negative impact for transport, postal and warehousing was probably mainly in transport, as lockdowns affected airlines and public transport. Some industries recovered well. For example, distribution probably accounts for the large increase in employment in accommodation and food services as, beyond the initial period, there was a massive expansion in home delivery of food. Gains in administrative and support services may be due to the time taken to develop alternative approaches to on-site working. The turnaround in mining was related to increases in demand from outside of Australia. In the case of iron ore, where exports and prices have expanded greatly, this was the result of the disruption that COVID-19 caused in other countries, especially Brazil (Ker 2020).

JobKeeper was clearly successful at maintaining attachment to the workplace, especially for higher level workers. However, in some industries, the data imply that employers were either ineligible for payments (with an insufficient reduction in turnover, or being an excluded organisation), chose not to enrol staff for JobKeeper, or employees were not eligible for payments. This particularly affected sectors with high casualisation or many migrant workers: JobKeeper was structured in favour of permanent employees and long-term casuals, and those with Australian residency.

Although there was little impact on the unemployment rate, job search duration increased over time, suggesting no churn in the unemployed and an increase in long-term unemployment. Initially, males were more affected by unemployment (particularly in arts and recreation services and accommodation and food services). 
There were industries where the pandemic itself stimulated employment, even in the initial period. This includes financial and insurance services, wholesale trade and construction. Businesses wishing to take advantage of various government schemes to support employment (especially JobKeeper) and people making personal decisions about their financial circumstances probably led to the early surge in employment in the financial and insurance services sector. Growth in construction was likely also related to the later 'HomeBuilder' stimulus program, which provided grants for homeowners to build, renovate and buy new-build homes.

The longer-term impacts by industry were very diverse, with some sectors benefitting substantially while some others suffered considerably. There remain major concerns about the employment of older workers in the industries where employment has remained low in the longer term, especially those with lower skill levels. Some sectoral shifts effected by COVID-19 - such as the growth of online shopping rather than retail, and the growth in food delivery - will particularly affect older workers' employment going forward. From past experience in the manufacturing industry, older workers who lose their jobs likely have great difficulty ever gaining work again and retire completely from the labour force (Callan \& Bowman 2015; Chomik 2020; OECD 2016). While this has negative consequences for income and superannuation, it can also affect mental health (which can also affect physical health), thereby further worsening financial circumstances through increased medical expenditure (Mandal \& Roe 2007). There may also be negative effects on the wellbeing of others in the household (Siegel et al. 2004). Those who do find work can have lower earnings due to shorter hours or lower hourly pay rates and often find themselves in precarious forms of employment.

Our analysis has used cross-sectional data tabulations from the ABS Labour Force Survey. This means our employment measures do not necessarily capture the same individuals. Rather, there could be churn with other labour market states hidden in these figures. Moreover, take-up of JobKeeper may have influenced employment results, with individuals classified as employed although they did not work. Future research could explore casualisation of the workforce more fully, potentially using longitudinal data from the Household, Income and Labour Dynamics in Australia (HILDA) survey or the ABS Longitudinal Labour Force dataset. Linked census data may also help to flesh out the longitudinal aspects. Space considerations meant we were unable to explore redundancy; the relationship between employment outcomes and working arrangements would also be of interest, as would exploring the gendered aspects of jobs that have been created post-COVID-19. It would also be useful to examine job search duration post-retrenchment. Future research could also consider the wider array of government stimulus measures, and how they have impacted job prospects in specific sectors.

\section{Conclusions}

Noting these limitations and extensions, our study provides evidence of the impact of the COVID-19 pandemic on labour force behaviour and outcomes for older Australians. Usually in recessions older workers fare worse than younger workers. However, in the recession induced by COVID-19 this did not always occur, as younger workers are more casualised and concentrated in affected industries.

The longer-term impacts by industry were very diverse, with some sectors benefitting substantially, while some others suffered considerably. This is the most important finding of the paper. By 
December 2020, employment levels for older workers in some sectors had recovered from the initial downturn caused by the pandemic. However, for older workers in some industries hard hit by the pandemic, there is a major concern about their potential for future employment. There remain major concerns about the employment of older workers in the industries where employment has remained low in the longer term, namely manufacturing; retail trade and information; media and telecommunications; and transport, postal and warehousing. Future government stimulus measures could be particularly aimed at supporting workers from these industries.

With the phase out of JobKeeper in 2021, and continued shutdowns in Victoria and New South Wales, it is important to track the continued impact of the COVID-19 pandemic on older workers and job seekers. With COVID now affecting employment in Australia's two most populous states, it is essential that research continues to consider the ongoing impacts of COVID on particular groups in the labour market in the medium and longer-term.

\section{Key messages}

- Overall employment rates for older workers fell in April 2020 but recovered by December.

- The longer-term impacts by industry were very diverse, with some sectors benefitting substantially, while others suffered considerably.

- There remain major concerns about the future employment prospects of older workers (particularly those with lower skill levels) in sectors where employment levels had not recovered by December 2020.

\section{Acknowledgments}

Funding was provided by COVID19 Impacts on Society Scheme, University of Melbourne. Fry, Temple and McDonald are funded by the Australian Research Council's Centre of Excellence in Population Ageing Research (CE1101029).

\section{References}

ABS (2018) Labour statistics: Concepts, sources and methods, Feb 2018. Canberra: ABS. https://www.abs.gov.au/ausstats/abs@.nsf/Lookup/by\%20Subject/6102.0.55.001 Feb\%202018 Main\%20Features Overview\%20of\%20Labour\%20Statistics 1. Accessed on 11 March 2021.

ABS (2021a) Dataset: Characteristics of employment, 2014-2020, Canberra: ABS. https://www.abs.gov.au/statistics/labour/earnings-and-work-hours/characteristics-employmentaustralia/latest-release. Accessed on 11 March 2021.

ABS (2021b) Dataset: Labour force Australia, detailed. Canberra: ABS. https://www.abs.gov.au/statistics/labour/employment-and-unemployment/labour-forceaustralia-detailed/latest-release. Accessed on 11 March 2021.

ABS (2021c) Labour Force, Australia methodology. Canberra: ABS. https://www.abs.gov.au/methodologies/labour-force-australia-methodology/jan-2021. Accessed on 11 March 2021.

Adair T \& Temple J (2012) Barriers to mature age labour force engagement in Australia: Canberra: Department of Education, Employment and Workplace Relations. https://nationalseniors.com.au/uploads/201208 PACReport Research BarriersMatureAgeEmplo yment Full 1.pdf 
Birch E \& Preston A (2021) The Australian labour market in 2020. Journal of Industrial Relations 63(3): 303-320. https://doi.org/10.1177/00221856211002224

Borland J \& Charlton A (2020) The Australian labour market and the early impact of COVID-19: an assessment. Australian Economic Review 53(3): 297-324. https://doi.org/10.1111/1467$\underline{8462.12386}$

Bui T T M, Button P, \& Picciotti E G (2020) Early evidence on the impact of COVID-19 and the recession on older workers. NBER Working Paper no. w27448. Cambridge, MA: National Bureau of Economic Research. https://doi.org/10.3386/w27448

Callan V J \& Bowman K (2015) Industry restructuring and job loss: Helping older workers get back into employment. Adelaide: National Centre for Vocational Education Research. https://www.ncver.edu.au/research-and-statistics/publications/all-publications/industryrestructuring-and-job-loss-helping-older-workers-get-back-into-employment

Chomik R (2020) COVID-19 and the demographic distribution of health and economic risks. ARC Centre of Excellence in Population Ageing Research Factsheet. Sydney: CEPAR. https://cepar.edu.au/sites/default/files/COVID-19-and-populations-at-risk.pdf

Churchill B (2020) COVID-19 and the immediate impact on young people and employment in Australia: A gendered analysis. Gender, Work \& Organization 28(2): 783-794. https://doi.org/10.1111/gwao.12563

Coates B, Cowgill M, Chen T, \& Mackey W (2020) Shutdown: estimating the COVID-19 employment shock. Melbourne: Grattan Institute. https://grattan.edu.au/report/shutdown-estimating-the-covid-19employment-shock/

Department of Health (2021) Coronavirus (COVID-19) current situation and case numbers. https://www.health.gov.au/news/health-alerts/novel-coronavirus-2019-ncov-healthalert/coronavirus-covid-19-current-situation-and-case-numbers\#cases-and-deaths-by-age-andsex. Accessed on 11 March 2021.

Forsyth A (2020) COVID-19 and labour law: Australia. Italian Labour Law e-Journal 13(1S). https://doi.org/10.6092/issn.1561-8048/10812

Ker P (2020) Brazil's Virus Pain to Extend Australia's Iron Ore Gain. Australian Financial Review, 28 September 2020.

Mandal B \& Roe B E (2007) Job loss, retirement and the mental health of older Americans. SSRN. http://dx.doi.org/10.2139/ssrn.991134

Neil I, Chin D, \& Parkin C (2021) The JobKeeper Scheme. Australian Journal of Labour Law 34: 24-42. https://advance.lexis.com/api/permalink/aebe5bcb-6da7-4e76-928cfc1fae2fcc93/?context=1201008\&federationidp=F2D4KJ52509.

OECD (1998) Work force ageing: consequences and policy responses, Working Paper AWP 4.1. Paris: OECD Publishing. https://www.oecd.org/els/public-pensions/2429096.pdf

OECD (2016) Back to work: Australia. Improving the re-employment prospects of displaced workers. Paris: OECD Publishing. https://www.oecd.org/employment/emp/Back-to-Work-Australia-AR.pdf

OECD (2020) Job retention schemes during the COVID-19 lockdown and beyond. Paris: OECD Publishing. https://www.oecd.org/coronavirus/policy-responses/iob-retention-schemes-during-the-covid19-lockdown-and-beyond-0853ba1d/

Rutledge M S \& Coe N B (2012) Great Recession-Induced Early Claimers: Who Are They? How Much Do They Lose? Center for Retirement Research Working Paper 2012-12. Boston MA: Boston College. https://crr.bc.edu/wp-content/uploads/2012/04/wp 2012-12-508.pdf

Siegel M J, Bradley E H, Gallo W T, \& Kasl S V (2004) The effect of spousal mental and physical health on husbands' and wives' depressive symptoms, among older adults: Longitudinal evidence from the health and retirement survey. Journal of Aging and Health 16: 398-425. https://doi.org/10.1177/0898264304264208 
Varma P, Junge M, Meaklim H, \& Jackson M (2021) Younger people are more vulnerable to stress, anxiety and depression during COVID-19 pandemic: a global cross-sectional survey. Progress in NeuroPsychopharmacology and Biological Psychiatry 109: 110236. https://doi.org/10.1016/i.pnpbp.2020.110236

Wood D, Griffiths K, \& Crowley T (2021) Women's work: The impact of the COVID crisis on Australian women. Melbourne: Grattan Institute. https:/grattan.edu.au/report/womens-work/

Yeatts D E, Folts W E, \& Knapp J (2000) Older workers adaptation to a changing workplace: Employment issues for the 21st century. Educational Gerontology 26(6): 565-582. https://doi.org/10.1080/03601270050133900 